\title{
ARTICLE
}

\section{Concomitant yield optimization of tannase and gallic acid by Bacillus licheniformis KBR6 through submerged fermentation: An industrial approach}

\author{
Pradeep K. Das Mohapatra1*, Ishita Biswas', Keshab C. Mondal², Bikas R. Pati² \\ ${ }^{1}$ Department of Microbiology, Raiganj University, Uttar Dinajpur-733 134, West Bengal, India \\ ${ }^{2}$ Department of Microbiology, Vidyasagar University, Midnapore-721 102, West Bengal, India
}

\begin{abstract}
The present study is concerned with the evaluation of tannase and gallic acid production efficacy of Bacillus licheniformis KBR6 under different environmental conditions through submerged fermentation. Results have shown that different environmental conditions and mineral sources have differential influences on tannase and gallic acid production. Highest tannase and gallic acid yield was observed at incubation period of $18 \mathrm{~h}$ and $22 \mathrm{~h}$, respectively. At tannic acid concentration of $15 \mathrm{~g} / \mathrm{l}$, maximum cell mass $(0.75 \mathrm{~g} / \mathrm{l})$, cell yield coefficient $(0.08 \mathrm{~g} / \mathrm{g})$, specific growth rate $(37.5 \mathrm{mg} / \mathrm{g} / \mathrm{h})$, tannase yield $(16.3 \mathrm{U} / \mathrm{g})$ and specific tannase production rate $(0.80 \mathrm{U} / \mathrm{g} / \mathrm{h})$ were observed, however, at higher tannic acid concentration a decrease in tannase yield and production rate were observed, but gallic acid production increased with increasing tannic acid concentration. Additional carbohydrate sources like glucose, fructose, and lactose showed positive influence on enzyme yield. Among the studied nitrogen sources urea and $\mathrm{NH}_{4} \mathrm{Cl}$, and of the phosphate sources $\mathrm{KH}_{2} \mathrm{PO}_{4}$ showed favourable effects on cell growth and simultaneous enzyme and gallic acid production. Temperature of $35^{\circ} \mathrm{C}$ was found to be optimum for tannase and gallic acid production. Of all the studied metal ions $\mathrm{Ca}^{2+}, \mathrm{Mg}^{2+}$ and $\mathrm{Na}^{+}$showed positive effect whereas, $\mathrm{Co}^{2+}, \mathrm{Ag}^{2+}, \mathrm{Pb}^{2+}, \mathrm{Hg}^{2+}$ showed inhibitory effects. Acta Biol Szeged 64(2):151-158 (2020)
\end{abstract}

\section{KEY WORDS}

Bacillus licheniformis KBR6 gallic acid submerged fermentation tannase

\section{ARTICLE INFORMATION}

Submitted

4 December 2020

Accepted

8 January 2021.

*Corresponding author

E-mail: pkdmvu@gmail.com

\section{Introduction}

Tannin acyl hydrolase (E.C. 3.1.1.20), which is commonly called tannase, is an inducible enzyme especially in microbes, produced in the presence of hydrolysable tannins (Barthomeuf et al. 1994; Mondal et al. 2001a; Mukherjee and Banerjee 2006). Tannase hydrolyses the ester and depside linkages of hydrolysable tannins like tannic acid, gallotannins, epigallocatechin-3-gallate, esters of gallic acid into glucose and gallic acid (Iibuchi et al. 1968; Das Mohapatra et al. 2005; Jana et al. 2014).

Tannase has wide applications in food, beverage, brewing, cosmetic and chemical industries (Lekha and Lonsane 1997; Aissam et al. 2005). It is mainly used for the preparation of gallic acid, instant tea, acorn wine, coffee flavoured soft drinks, high-grade leather tannin, clarification of beer and fruit juice, detannification of food and production of wine (Coggon and Sanderson 1972; Lekha and Lonsane 1997; Mukherjee and Banerjee 2003; Aracri et al. 2019; Cavalcanti et al. 2020). It is also used to clean up highly polluting tannin from the effluent of the leather industry (Kim et al. 2020; Biswas et al. 2020).
Besides that, gallic acid (3,4,5, trihydroxy benzoic acid), a hydrolyzable product of tannic acid is an antioxidant and has several uses for the manufacture of propyl gallate, photosensitive resin, pyrogallol, ink and dye (Gaathon et al. 1989; Das Mohapatra et al. 2005; Patil et al. 2011). Conventionally it is produced from tannic acid by acid hydrolysis or by the action of enzyme tannase (Lekha and Lonsane 1997). Microbial process is the most specific, eco-friendly and cost-effective approach and at the same time pure gallic acid could be recovered from the process easily. The world-wide annual demand of gallic acid is about 8000 tones (Lokeswari 2010; Aguilar-Zarate et al. 2015). In India it is totally imported and mainly utilized as an intermediate in the production of trimethoxy benzaldehyde, which is used in the pharmaceutical industry to produce trimethoprim, a broad-spectrum antibiotic (Bajpai and Patil 1997; Aissam et al. 2005; Biswas et al. 2020). A combination of trimethoprim and sulphonamide is effective against many otherwise resistant species of bacteria.

Though tannic acid is generally considered as antinutrient and antimicrobial agent (Scalbert 1991), however, a large number of tannase-producing microorganisms 
including bacteria, fungi and yeast can hydrolyse tannic acid into gallic acid and glucose (Mondal and Pati 2000; Banerjee et al. 2001; Sharma et al. 2007; Das Mohapatra et al. 2009). Production of tannase and gallic acid in tannin rich media through fungi has been reported earlier by many researchers (Rajakumar and Nandy 1983; Pourrat et al. 1987; Hadi et al.1994; Bajpai and Patil 1999; Banerjee et al. 2001; Mukherjee and Banerjee 2006). In this context there are comparatively few reports on simultaneous production of the two by bacteria. Using chestnut tannin as carbon source, Deschamps et al. (1983) first reported the production of extracellular tannase by Bacillus pumilus, Bacillus polymixa, Corynebacterium sp. and Klebsiella pneumoniae. Later, Deschamps and Lebeault (1984) reported the production of gallic acid from tara pod tannins by $K$. pneumoniae and Corynebacterium sp. Tannase-producing strains like Streptococcus sp. from faeces of koalas (Osawa and Mitsuoka 1990) and Lactobacilli from humans and fermented foods (Osawa et al. 2000) were also reported. Das Mohapatra et al. (2006) reported on tannase production by Bacillus licheniformis KBR6 by using eight different (Acacia auriculiformis, Casuarina quisetifolia, Psidium guazava, Anacardium occidentale, Delonix regia, Eucalyptus tereticornis, Cassia fistula, and Ficus bengalensis) plant extracts as tannin source. Aguilar-Zarate et al. (2015) reported on gallic acid production under anaerobic submerged fermentation by two bacilli strains identified as Bacillus subtilis AM1 and Lactobacillus plantarum CIR1. A preliminary study was done on isolation of tannase producer from soil, like $B$. licheniformis KBR6 and Bacillus cereus KBR9 (Mondal and Pati 2000; Mondal et al. 2001a).

Submerged fermentation involves the growth of the microorganism in a liquid medium in which various nutrients are either dissolved or suspended as particulate solids (Frost and Moss 1987). Submerged fermentation is mostly preferred, because sterilization and process control mechanisms are quite easier (Lekha and Lonsane 1997). In submerged fermentation, uniform growth of the microorganism occurred as a suspension owing to various gases and nutrients, which are either dissolved or suspended in a liquid medium (Frost and Moss 1987).

In this present work the tannase and gallic acid yield efficiency of $B$. licheniformis KBR6 through submerged fermentation has been studied.

\section{Materials and Methods}

\section{Microorganism and mode of cultivation}

A potent tannase-producing bacterium used in the present study was isolated from the lateritic sal forest soil of Midnapore district, West Bengal, India and was identified as B. licheniformis KBR6 (IMI. No.-379224) (Mondal and Pati 2000).

The selective medium used for growth of the organism was composed of (g/l): tannic acid, $10 ; \mathrm{K}_{2} \mathrm{HPO}_{4}, 0.5$; $\mathrm{KH}_{2} \mathrm{PO}_{4}, 0.5 ; \mathrm{MgSO}_{4} 0.5 ; \mathrm{CaCl}_{2}, 1.0 ; \mathrm{NH}_{4} \mathrm{Cl}, 3.0$. The $\mathrm{pH}$ of sterilized medium was adjusted to 5.0 using 0.5 $\mathrm{M} \mathrm{NaOH}$. Cultivation of B. licheniformis KBR6 was done in $250 \mathrm{ml}$ Erlenmeyer flask containing $50 \mathrm{ml}$ sterilized medium for $20 \mathrm{~h}$ on a rotary shaker $(200 \mathrm{rpm})$ at $35^{\circ} \mathrm{C}$. The culture broth was centrifuged (5000 g for $15 \mathrm{~min}$ ) and the supernatant was examined for production of tannase as well as gallic acid.

\section{Determination of microbial growth}

For measuring the growth, the cell concentration was determined by turbidimetry at $620 \mathrm{~nm}$ (SL 171 Mini Spec, Elico, India) and correlated to cell dry weight (mg/ml).

\section{Measurement of tannin concentration}

The remaining tannin content of the fermented broth was estimated by the modified method of Hagerman and Butler (1978). The tannin content of the fermented broth $(0.5 \mathrm{ml})$ was precipitated by addition of $3 \mathrm{ml}$ of BSA solution $(1 \mathrm{mg} / \mathrm{ml})$ and kept at room temperature for $15 \mathrm{~min}$. After centrifugation $(5000 \mathrm{~g}, 5 \mathrm{~min})$, the precipitate was dissolved in $3 \mathrm{ml}$ of SDS - triethanolamine solution (SDS $1 \%, \mathrm{w} / \mathrm{v}$, and triethanolamine $5 \%, \mathrm{v} / \mathrm{v}$, in distilled water). Then $1 \mathrm{ml}$ of $\mathrm{FeCl}_{3}$ reagent $\left(0.01 \mathrm{M} \mathrm{FeCl}_{3}\right.$ in $\left.0.01 \mathrm{~N} \mathrm{HCl}\right)$ was added and incubated for $30 \mathrm{~min}$ for stabilization of colour. This coloured solution was diluted with distilled water and the absorbency was measured at $530 \mathrm{~nm}$. The residual tannic acid in the fermented broth was determined from a standard curve and expressed as percentage of initial concentration.

\section{Assay of tannase}

The activity of extracellular tannase from $B$. licheniformis KBR6 was determined by the colorimetric method of Mondal et al. (2001b). For the assay, $0.1 \mathrm{ml}$ of enzyme was mixed with $0.3 \mathrm{ml}$ of tannic acid substrate solution $(1.0 \% \mathrm{w} / \mathrm{v}$ tannic acid in $0.2 \mathrm{M}$ citrate buffer, $\mathrm{pH} 5.0$ ), and incubated at $50{ }^{\circ} \mathrm{C}$ for $30 \mathrm{~min}$. The reaction was terminated by the addition of BSA solution $(1 \mathrm{mg} / \mathrm{ml})$, which also precipitated the residual tannic acid. A control reaction with heat-denatured enzyme was performed concomitantly. The tubes were then centrifuged (5000 $\mathrm{g}, 10 \mathrm{~min}$ ) and the precipitates were dissolved in $2 \mathrm{ml}$ of SDS-triethanolamine ( $1 \% \mathrm{w} / \mathrm{v}$, SDS in $5 \% \mathrm{v} / \mathrm{v}$, triethanolamine) solution. The absorbance was measured at $530 \mathrm{~nm}$ after addition of $1 \mathrm{ml}$ of $0.13 \mathrm{M} \mathrm{FeCl}_{3}$.

The specific extinction coefficient of tannic acid at 530 $\mathrm{nm}$ was 0.577 (Mondal et al. 2001b). Using this coefficient, one unit of tannase activity was defined as the amount of enzyme that can hydrolyse $1 \mu \mathrm{M}$ of ester linkage of 
tannic acid in $1 \mathrm{~min}$ at $50{ }^{\circ} \mathrm{C}$ and $\mathrm{pH} 5.0$.

\section{Estimation of gallic acid}

The gallic acid in the culture medium was estimated following the method of Bajpai and Patil (1996). Culture supernatant was diluted 100 -fold with $0.5 \mathrm{M}$ acetate buffer ( $\mathrm{pH}$ 6.0) and the absorbance was simultaneously measured at two specific wavelengths. Concentration of gallic acid was calculated by the following equation:

$$
\text { Gallic acid }(\mu \mathrm{g} / \mathrm{ml})=21.77\left(\mathrm{~A}_{254.6}\right)-17.17\left(\mathrm{~A}_{293.8}\right)
$$

\section{Results}

\section{Effect of incubation period}

Tannase and gallic acid production in relation to growth of B. licheniformis KBR6 were studied in submerged fermentation for $48 \mathrm{~h}$. The formation of tannase was started from the early stages of growth of the bacterium and reached maximum at $18 \mathrm{~h}$. The highest gallic acid production was found at $22 \mathrm{~h}$ (Fig. 1).

\section{Effect of tannic acid concentration}

The catalytic activity of $B$. licheniformis KBR6 was studied in a fermentation medium containing various tannic acid (sole substrate) concentrations (5 to $40 \mathrm{~g} / \mathrm{l}$ ) and represented in Table 1. Increasing the initial tannic acid concentration from 10 to $15 \mathrm{~g} / \mathrm{l}$ favoured the growth of the organism. At $15 \mathrm{~g} / 1$ tannic acid concentration maximum cell mass $(0.75 \mathrm{~g} / \mathrm{l})$, cell yield co-efficient $(0.08 \mathrm{~g} / \mathrm{g})$ and specific growth rate $(37.5 \mathrm{mg} / \mathrm{g} / \mathrm{h})$ of the organism was observed. The highest tannase yield $(16.3 \mathrm{U} / \mathrm{g})$ and specific tannase production rate $(0.80 \mathrm{U} / \mathrm{g} / \mathrm{h})$ were also obtained in this tannic acid concentration. It was also shown that somewhat higher concentration of tannic acid

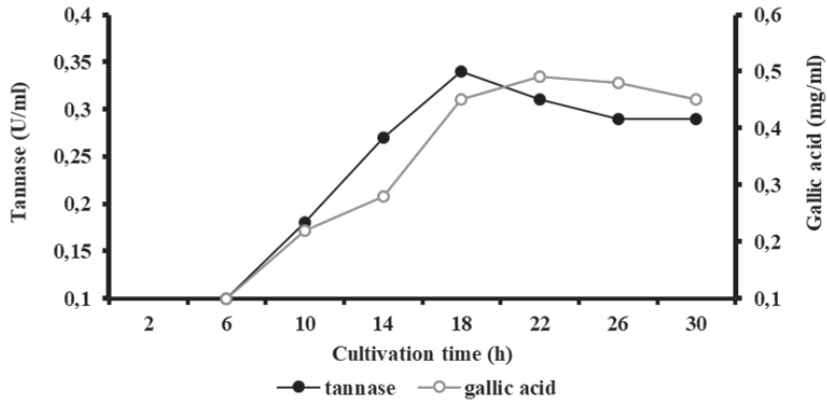

Figure 1. Effect of incubation period on tannase and gallic acid production.

$(20 \mathrm{~g} / \mathrm{l})$ decreased tannase yield $(15.2 \mathrm{U} / \mathrm{g})$ and specific tannase production rate $(0.76 \mathrm{U} / \mathrm{g} / \mathrm{h})$. But the gallic acid yield coefficient and specific gallic acid production rate increased with increase in tannic acid concentration.

\section{Effect of additional carbohydrate (extra carbon source) in tannic acid medium}

Carbon source is known to influence the growth as well as constitutive element in the synthesis of any metabolite. In order to assess the effects of additional carbohydrates on the growth, extracellular tannase formation and gallic acid production by $B$. licheniformis KBR6, four different carbohydrates (2 g/l) viz, glucose, fructose, sucrose and lactose were added to the medium separately and then examined (Table 2). Maximum cell growth, gallic acid yield coefficient and specific growth rate of the organism were obtained in presence of glucose and fructose, whereas tannase yield coefficient and specific tannase production rate showed highest in presence of lactose. In absence of any additional carbon source, the catalytic activity of organism was significantly reduced.

Table 1. Effect of tannic acid concentration on gallic acid, tannase, and cell mass formation by $B$. licheniformis KBR6.

\begin{tabular}{llllllllll}
\hline Parameters & Without tannic acid & \multicolumn{7}{c}{ Tannic acid (g/l) } \\
\cline { 3 - 9 } & & 5 & 10 & 15 & 20 & 25 & 30 & 35 \\
\hline $\mathrm{C}_{\mathrm{cm}}$ & 0.23 & 0.66 & 0.74 & 0.75 & 0.68 & 0.50 & 0.30 & 0.30 & 0.19 \\
$\mathrm{Y}_{\mathrm{c} / \mathrm{s}}$ & 0.23 & 0.07 & 0.07 & 0.08 & 0.07 & 0.05 & 0.03 & 0.03 & 0.02 \\
$\mathrm{Y}_{\mathrm{e} / \mathrm{s}}$ & $\mathrm{ND}$ & 8.1 & 14.1 & 16.3 & 15.2 & 12.4 & 11.3 & 10.9 & 7.8 \\
$\mathrm{Y}_{\mathrm{g} / \mathrm{s}}$ & $\mathrm{ND}$ & 61.4 & 75.8 & 77.5 & 80.0 & 80.0 & 82.0 & 84.0 & 83.0 \\
$\mathrm{q}_{\mathrm{e}}$ & $\mathrm{ND}$ & 0.41 & 0.71 & 0.80 & 0.76 & 0.62 & 0.57 & 0.57 & 0.39 \\
$\mathrm{q}_{\mathrm{g}}$ & $\mathrm{ND}$ & 3.0 & 3.1 & 3.8 & 4.1 & 4.06 & 4.1 & 4.2 & 4.3 \\
$\mathrm{q}_{\mathrm{c}}$ & 11 & 33 & 37 & 37.5 & 34 & 25 & 15 & 15 & 9 \\
$\mathrm{~S} / \mathrm{s}$ & $\mathrm{ND}$ & 82.2 & 83.1 & 78.0 & 66.3 & 46.0 & 45.8 & 45.6 & 32.3 \\
\hline
\end{tabular}

$\mathrm{ND}=$ Non detectable; $\mathrm{C}_{\mathrm{cm}}=$ dry cell mass $(\mathrm{g} / \mathrm{l}) ; \mathrm{Y}_{\mathrm{c} / \mathrm{s}}=$ cell yield coefficient ( $\mathrm{g}$ dry cell mass per $\mathrm{g}$ tannic acid used); $\mathrm{Y}_{\mathrm{e} / \mathrm{s}}=$ tannase yield coefficient $(\mathrm{U}$ of enzyme per $\mathrm{g}$ tannic acid used); $\mathrm{Y}_{\mathrm{g} / \mathrm{s}}=$ gallic acid yield coefficient ( $\mathrm{g}$ of gallic acid per $\mathrm{g}$ tannic acid used); $\mathrm{q}_{\mathrm{e}}=$ tannase production rate (U/g/h); $\mathrm{q}_{\mathrm{g}}=$ gallic acid production rate $(\mathrm{mg} / \mathrm{g} / \mathrm{h}) ; \mathbf{q}_{\mathrm{c}}=$ growth rate $(\mathrm{mg} / \mathrm{g} / \mathrm{h}) ; \mathrm{S} / \mathrm{s}=$ tannic acid consumed percentage 
Mohapatra et al.

Table 2. Effect of carbon source ( $2 \mathrm{~g} / \mathrm{l})$ on tannase, gallic acid and cell mass formation by B. licheniformis KBR6.

\begin{tabular}{llllll}
\hline Parameters & No carbohydrate & Glucose & Fructose & Sucrose & Lactose \\
\hline $\mathrm{C}_{\mathrm{cm}}$ & 0.41 & 0.7 & 0.71 & 0.67 & 0.66 \\
$\mathrm{Y}_{\mathrm{c} / \mathrm{s}}$ & 0.04 & 0.07 & 0.07 & 0.07 & 0.07 \\
$\mathrm{Y}_{\mathrm{e} / \mathrm{s}}$ & 3.9 & 4.5 & 4.2 & 6.1 & 6.5 \\
$\mathrm{Y}_{\mathrm{g} / \mathrm{s}}$ & 0.125 & 0.269 & 0.252 & 0.216 & 0.185 \\
$\mathrm{q}_{\mathrm{e}}$ & 0.195 & 0.225 & 0.21 & 0.305 & 0.325 \\
$\mathrm{q}_{\mathrm{g}}$ & 4.1 & 4.3 & 4.4 & 4.4 & 4.0 \\
$\mathrm{q}_{\mathrm{c}}$ & 20 & 35 & 35 & 33 & 33 \\
$\mathrm{~S} / \mathrm{s}$ & 66.2 & 32.2 & 35.0 & 40.8 & 44.2 \\
\hline
\end{tabular}

$\mathrm{C}_{\mathrm{cm}}=$ dry cell mass $(\mathrm{g} / \mathrm{l}) ; \mathrm{Y}_{\mathrm{c} / \mathrm{s}}=$ cell yield coefficient (g dry cell mass per g tannic acid used); $\mathrm{Y}_{\mathrm{e} / \mathrm{s}}=$ tannase yield coefficient ( $\mathrm{U}$ of enzyme per $\mathrm{g}$ tannic acid used); $\mathrm{Y}_{\mathrm{g} / \mathrm{s}}=$ gallic acid yield coefficient ( $\mathrm{g}$ of gallic acid per g tannic acid used); $\mathrm{q}_{\mathrm{e}}=$ tannase production $\mathrm{rate}(\mathrm{U} / \mathrm{g} / \mathrm{h}) ; \mathrm{q}_{\mathrm{g}}=$ gallic acid production rate $(\mathrm{mg} / \mathrm{g} / \mathrm{h}) ;$ $\mathrm{q}_{\mathrm{c}}=$ growth rate $(\mathrm{mg} / \mathrm{g} / \mathrm{h}) ; \mathrm{S} / \mathrm{s}=$ tannic acid consumed percentage

Table 3 Effect of nitrogen source (3 g/l) on tannase, gallic acid and cell mass formation by B. licheniformis KBR6.

\begin{tabular}{lllllllll}
\hline Parameter & No $\mathbf{N}_{2}$ source & Urea & $\mathbf{N H}_{4} \mathbf{C l}$ & $\mathbf{~ N H}_{4} \mathbf{S O}_{2} \mathbf{S}$ & $\mathbf{N H}_{4} \mathbf{N O}_{3}$ & $\mathbf{N a N O}_{3}$ & Creatinine & Ammonium oxalate \\
\hline $\mathrm{C}_{\mathrm{cm}}$ & 0.34 & 0.78 & 0.74 & 0.71 & 0.73 & 0.07 & 0.08 & 0.07 \\
$\mathrm{Y}_{\mathrm{c} / \mathrm{s}}$ & 0.03 & 0.08 & 0.07 & 0.07 & 0.07 & 0.01 & 0.01 & 0.01 \\
$\mathrm{Y}_{\mathrm{e} / \mathrm{s}}$ & 2.1 & 9.4 & 14.8 & 7.1 & 11.7 & 2.8 & 2.8 & 5.5 \\
$\mathrm{Y}_{\mathrm{g} / \mathrm{s}}$ & 0.011 & 0.052 & 0.082 & 0.068 & 0.08 & 0.028 & 0.022 & 0.022 \\
$\mathrm{q}_{\mathrm{e}}$ & 0.11 & 0.47 & 0.74 & 0.355 & 0.585 & 0.14 & 0.14 & 0.275 \\
$\mathrm{q}_{\mathrm{g}}$ & $\mathrm{ND}$ & 2.6 & 4.1 & 3.4 & 4.0 & 1.4 & 1.1 & 1.1 \\
$\mathrm{q}_{\mathrm{c}}$ & 10 & 39 & 37 & 35 & 36 & 3 & 4 & 3 \\
$\mathrm{~S} / \mathrm{s}$ & 12 & 63.2 & 54 & 43.4 & 50.1 & 11.4 & 12.9 & 10.9 \\
\hline
\end{tabular}

$\mathrm{ND}=$ Non detectable; $\mathrm{C}_{\mathrm{cm}}=$ dry cell mass $(\mathrm{g} / \mathrm{l}) ; \mathrm{Y}_{\mathrm{c} / \mathrm{s}}=$ cell yield coefficient $\left(\mathrm{g}\right.$ dry cell mass per $\mathrm{g}$ tannic acid used); $\mathrm{Y}_{\mathrm{e} / \mathrm{s}}=$ tannase yield coefficient $(\mathrm{U}$ of enzyme per $\mathrm{g}$ tannic acid used); $\mathrm{Y}_{\mathrm{g} / \mathrm{s}}=$ gallic acid yield coefficient ( $\mathrm{g}$ of gallic acid per $\mathrm{g}$ tannic acid used); $\mathrm{q}_{\mathrm{e}}=$ tannase production rate $(\mathrm{U} / \mathrm{g} / \mathrm{h}) ; \mathrm{q}_{\mathrm{g}}=\mathrm{gallic}$ acid production rate $(\mathrm{mg} / \mathrm{g} / \mathrm{h}) ; \mathrm{q}_{\mathrm{c}}=$ growth rate $(\mathrm{mg} / \mathrm{g} / \mathrm{h}) ; \mathrm{S} / \mathrm{s}=$ tannic acid consumed percentage

\section{Effect of nitrogen source}

The nitrogen source is an essential prerequisite for metabolic reaction of any living cell. In order to find out the suitable nitrogen source for tannase and gallic acid production, B. licheniformis KBR6 was grown in presence of various nitrogen sources (Table 3), and each nitrogen source was added to the basal medium at a concentration of $3 \mathrm{~g} / \mathrm{l}$ Urea and $\mathrm{NH}_{4} \mathrm{Cl}$ showed a favourable effect in respect to growth of the organism as well as gallic acid and enzyme production. Though the maximum growth of the bacterium occurred in the presence of urea, but the higher enzyme induction was observed in the presence of $\mathrm{NH}_{4} \mathrm{Cl}$. It is also observed that the gallic acid yield coefficient, the specific tannase and gallic acid production rates were also higher in presence of $\mathrm{NH}_{4} \mathrm{Cl}$. In relation to higher growth of bacteria, the tannic acid consumption percentage in presence of urea is much more (63.2\%) as compared to other nitrogen sources. A negligible effect was observed in presence of the other nitrogen sources like $\mathrm{NaNO}_{3}$, creatinine and ammonium oxalate.

\section{Effect of phosphate source}

The effect of different inorganic phosphates $\left(\mathrm{KH}_{2} \mathrm{PO}_{4}\right.$,

Table 4 Effect of phosphate source $(0.5 \mathrm{~g} / \mathrm{l})$ on tannase, gallic acid and cell mass formation by $B$. licheniformis KBR6.

\begin{tabular}{lllll}
\hline Parameters & No phosphate source & $\mathbf{K H}_{2} \mathbf{P O}_{4}$ & $\mathbf{K}_{2} \mathbf{H P O}_{4}$ & $\left(\mathbf{N H}_{4}\right)_{2} \mathbf{H P O}_{4}$ \\
\hline $\mathrm{C}_{\mathrm{cm}}$ & 0.12 & 0.95 & 0.84 & 0.62 \\
$\mathrm{Y}_{\mathrm{c} / \mathrm{s}}$ & 0.01 & 0.10 & 0.08 & 0.06 \\
$\mathrm{Y}_{\mathrm{e} / \mathrm{s}}$ & 1.0 & 16.5 & 14.2 & 6 \\
$\mathrm{Y}_{\mathrm{g} / \mathrm{s}}$ & 0.11 & 0.071 & 0.069 & 0.058 \\
$\mathrm{q}_{\mathrm{e}}$ & 0.015 & 0.825 & 0.71 & 0.3 \\
$\mathrm{q}_{\mathrm{g}}$ & 1 & 3.5 & 3.4 & 2.9 \\
$\mathrm{q}_{\mathrm{c}}$ & 6 & 47 & 42 & 31 \\
$\mathrm{~S} / \mathrm{s}$ & 1.73 & 82.2 & 75.8 & 45 \\
\hline
\end{tabular}

$\mathrm{ND}=$ Non detectable; $\mathrm{C}_{\mathrm{cm}}=$ dry cell mass $(\mathrm{g} / \mathrm{l}) ; \mathrm{Y}_{\mathrm{c} / \mathrm{s}}=$ cell yield coefficient $(\mathrm{g}$ dry cell mass per $\mathrm{g}$ tannic acid used); $\mathrm{Y}_{\mathrm{e} / \mathrm{s}}=$ tannase yield coefficient $(\mathrm{U}$ of enzyme per $\mathrm{g}$ tannic acid used); $\mathrm{Y}_{\mathrm{g} / \mathrm{s}}=$ gallic acid yield coefficient ( $\mathrm{g}$ of gallic acid per $\mathrm{g}$ tannic acid used); $\mathrm{q}_{\mathrm{e}}=$ tannase production rate $(\mathrm{U} / \mathrm{g} / \mathrm{h}) ; \mathrm{q}_{\mathrm{g}}=$ gallic acid production rate $(\mathrm{mg} / \mathrm{g} / \mathrm{h}) ; \mathbf{q}_{\mathrm{c}}=$ growth rate $(\mathrm{mg} / \mathrm{g} / \mathrm{h}) ; \mathrm{S} / \mathrm{s}=$ tannic acid consumed percentage 
Table 5 Effect of temperature on tannase and gallic acid production by B. licheniformis KBR6.

\begin{tabular}{|c|c|c|c|c|c|c|}
\hline Parameter & $20^{\circ} \mathrm{C}$ & $25^{\circ} \mathrm{C}$ & $30^{\circ} \mathrm{C}$ & $35^{\circ} \mathrm{C}$ & $40^{\circ} \mathrm{C}$ & $45^{\circ} \mathrm{C}$ \\
\hline$C_{c m}$ & 0.15 & 0.25 & 0.32 & 0.52 & 0.27 & 0.25 \\
\hline$Y_{c / s}$ & 0.05 & 0.06 & 0.07 & 0.08 & 0.07 & 0.06 \\
\hline $\mathrm{Y}_{\mathrm{e} / \mathrm{s}}$ & 2.9 & 6.5 & 11.3 & 14.4 & 10.2 & 5.3 \\
\hline$Y_{g / s}$ & 0.0 & 3.3 & 5.2 & 6.5 & 4.5 & 2.0 \\
\hline
\end{tabular}

$\mathrm{C}_{\mathrm{cm}}=$ dry cell mass $(\mathrm{g} / \mathrm{l}) ; \mathrm{Y}_{\mathrm{c} / \mathrm{s}}=$ cell yield coefficient ( $\mathrm{g}$ dry cell mass per $\mathrm{g}$ tannic acid used); $\mathrm{Y}_{\mathrm{e} / \mathrm{s}}=$ tannase yield coefficient $(\mathrm{U}$ of enzyme per $\mathrm{g}$ tannic acid used); $\mathrm{Y}_{\mathrm{g} / \mathrm{s}}=$ gallic acid yield coefficient ( $\mathrm{g}$ of gallic acid per $\mathrm{g}$ tannic acid used)

$\mathrm{K}_{2} \mathrm{HPO}_{4}$ and $\left.\left(\mathrm{NH}_{4}\right)_{2} \mathrm{HPO}_{4}\right)$ was studied for tannase and gallic acid production by $B$. licheniformis KBR6. It has been observed that phosphate source in tannic acid medium is essential for bacterial growth and tannase production (Table 4). In this experiment $0.5 \mathrm{~g} / 1$ of all the phosphate sources were used. The maximum gallic acid production, tannase yield co-efficient and specific rate of enzyme synthesis by the organism occurred in presence of $\mathrm{KH}_{2} \mathrm{PO}_{4}$ (Table 4). Whereas, the efficiency of the organism was similar for growth, tannase and gallic acid production in presence of both $\mathrm{KH}_{2} \mathrm{PO}_{4}$ and $\mathrm{K}_{2} \mathrm{HPO}_{4}$.

\section{Effect of temperature}

To find out optimum temperature for growth and tannase production the organism was grown at different temperature $\left(20-50{ }^{\circ} \mathrm{C}\right)$. It was found that the organism could able to grow in between $20-45^{\circ} \mathrm{C}$. But maximum cell mass growth, tannase and gallic acid yield coefficient were observed at $35^{\circ} \mathrm{C}$ (Table 5).

\section{Effect of initial medium $\mathrm{pH}$}

Significant growth of organism and tannase and gallic acid production by the organism were observed in the wide range of $\mathrm{pH}$ (3.0 to 6.5), but maximum cell mass growth, tannase yield coefficient were found at $\mathrm{pH}$ 5.0, whereas highest gallic acid yield coefficient was observed at pH 5.5 (Table 6).

\section{Effect of metal ions}

Different cations $(0.05 \%, \mathrm{w} / \mathrm{v})$ were added in tannic acid medium to study their effects on growth, tannase and gallic acid production (Table 7). It has been observed that $\mathrm{Ca}^{2+}, \mathrm{Mg}^{2+}$ and $\mathrm{Na}^{+}$ions in tannic acid medium increased growth of microorganism, tannase and gallic acid production. Other metal ions like $\mathrm{Mn}^{2+}, \mathrm{Co}^{2+}, \mathrm{Ag}^{2+}$, $\mathrm{Pb}^{2+}, \mathrm{Hg}^{2+}$ were inhibitory to bacterial growth as well as tannase and gallic acid production.

\section{Discussion}

Simultaneous production of tannase and gallic acid by bacteria has comparatively little report. In comparison to fungal strains, bacteria are highly sensitive to tannic acid (Scalbert 1991). The organism B. licheniformis KBR6 produced maximum tannase and gallic acid at its active $\log$ phases (18 $\mathrm{h}$ and $22 \mathrm{~h}$, respectively). It has also been observed that tannase production was directly proportional to the early (up to $20 \mathrm{~h}$ ) growth of the organism. In this regard, Deschamp et al. (1983) reported that Corynebacterium sp. able to produce maximum tannase at early stages $(6 \mathrm{~h})$ of growth but the organism attained highest growth after $24 \mathrm{~h}$. Similar findings were reported by Selwal et al. (2010) where enzyme production by Pseudomonas aeruginosa IIIB 8914 was started from its early growth but reached the highest level at $24 \mathrm{~h}$, after which it get decreased.

Increasing the initial tannic acid concentration from 10 to $15 \mathrm{~g} / \mathrm{l}$ favoured the growth of the organism. Furthermore, increasing substrate concentration (above 15

Table 6 Effect of $\mathrm{pH}$ on tannase and gallic acid production by B. licheniformis KBR6.

\begin{tabular}{llllllll}
\hline Parameter & $\mathbf{3 . 0}$ & $\mathbf{4 . 0}$ & $\mathbf{4 . 5}$ & $\mathbf{5 . 0}$ & $\mathbf{5 . 5}$ & $\mathbf{6 . 0}$ & $\mathbf{6 . 5}$ \\
\hline $\mathrm{C}_{\mathrm{cm}}$ & 0.12 & 0.25 & 0.32 & 0.43 & 0.38 & 0.28 & 0.20 \\
$\mathrm{Y}_{\mathrm{c} / \mathrm{s}}$ & 0.04 & 0.05 & 0.06 & 0.08 & 0.07 & 0.05 & 0.05 \\
$\mathrm{Y}_{\mathrm{e} / \mathrm{s}}$ & 4.2 & 5.6 & 8.2 & 15.2 & 9.3 & 7.5 & 5.2 \\
$\mathrm{Y}_{\mathrm{g} / \mathrm{s}}$ & 2.0 & 3.3 & 4.2 & 5.5 & 6.5 & 4.2 & 2.2 \\
\hline
\end{tabular}

$\mathrm{C}_{\mathrm{cm}}=$ dry cell mass $(\mathrm{g} / \mathrm{l}) ; \mathrm{Y}_{\mathrm{c} / \mathrm{s}}=$ cell yield coefficient ( $\mathrm{g}$ dry cell mass per $\mathrm{g}$ tannic acid used); $\mathrm{Y}_{\mathrm{e} / \mathrm{s}}=$ tannase yield coefficient ( $\mathrm{U}$ of enzyme per $\mathrm{g}$ tannic acid $\mathrm{used}$ ); $\mathrm{Y}_{\mathrm{g} / \mathrm{s}}=$ gallic acid yield coefficient ( $\mathrm{g}$ of gallic acid per $\mathrm{g}$ tannic acid used) 
Mohapatra et al.

Table 7 Effect of metal ions on growth, tannase and gallic acid production.

\begin{tabular}{llll}
\hline lons $(\mathbf{0 . 0 5} \% \mathbf{w} / \mathbf{v})$ & Dry biomass $(\mathbf{m g} / \mathbf{m l})$ & Tannase $(\mathbf{U} / \mathbf{m l})$ & Gallic acid $(\mathbf{m g} / \mathbf{m l})$ \\
\hline Control & $0.35 \pm 0.03$ & $0.30 \pm 0.06$ & $0.42 \pm 0.08$ \\
$\mathrm{AgCl}_{2}$ & $\mathrm{ND}$ & $\mathrm{ND}$ & $\mathrm{ND}$ \\
$\mathrm{BaCl}_{2}$ & $0.12 \pm 0.03$ & $0.08 \pm 0.02$ & $0.13 \pm 0.01$ \\
$\mathrm{CaCl}_{2}$ & $0.36 \pm 0.08$ & $0.33 \pm 0.04$ & $0.45 \pm 0.01$ \\
$\mathrm{CoCl}_{2}$ & $0.13 \pm 0.02$ & $0.08 \pm 0.03$ & $0.12 \pm 0.03$ \\
$\mathrm{CuCl}_{2}$ & $\mathrm{ND}$ & $\mathrm{ND}$ & $\mathrm{ND}$ \\
$\mathrm{HgCl}_{2}$ & $0.09 \pm 0.04$ & $0.06 \pm 0.01$ & $\mathrm{ND}$ \\
$\mathrm{MgCl}_{2}$ & $0.35 \pm 0.05$ & $0.37 \pm 0.01$ & $0.48 \pm 0.05$ \\
$\mathrm{MnCl}_{2}$ & $\mathrm{ND}$ & $\mathrm{ND}$ & $\mathrm{ND}$ \\
$\mathrm{NaCl}$ & $0.42 \pm 0.06$ & $0.33 \pm 0.08$ & $0.45 \pm 0.14$ \\
$\mathrm{PbCl}_{2}$ & $0.18 \pm 0.03$ & $0.14 \pm 0.06$ & $0.12 \pm 0.01$ \\
$\mathrm{CaCl}_{2}+\mathrm{MgCl}$ & $0.85 \pm 0.10$ & $0.35 \pm 0.07$ & $0.45 \pm 0.03$ \\
$\mathrm{MgCl}_{2}+\mathrm{NaCl}$ & $0.72 \pm 0.09$ & $0.36 \pm 0.10$ & $0.45 \pm 0.04$ \\
$\mathrm{CaCl}_{2}+\mathrm{NaCl}$ & $0.63 \pm 0.07$ & $0.31 \pm 0.11$ & $0.38 \pm 0.02$ \\
$\mathrm{MgCl}_{2}+\mathrm{NaCl}+\mathrm{CaCl}_{2}$ & $0.92 \pm 0.11$ & $0.43 \pm 0.05$ & $0.55 \pm 0.09$ \\
\hline
\end{tabular}

ND = Non detectable

$\mathrm{g} / \mathrm{l})$ resulted significant inhibition of bacterial growth as well as other growth-related parameters. This reveals that growth of $B$. licheniformis KBR6 is highly regulated by the tannic acid concentration in medium. The retardation of growth at higher tannic acid concentration was due to toxicity of substrate itself as it contained large quantity of phenolic groups, which causes precipitation of macromolecules including proteins and carbohydrates (Lewis and Starkey 1969; Scalbert 1991). In this experiment, an increment in the specific production rate and yield of gallic acid was observed with increasing the initial tannic acid concentration up to $20 \mathrm{~g} / \mathrm{l}$ and after which there were no significant alteration observed with further enhancement of tannic acid. The initial rapid production of gallic acid was due to increase in growth as well as higher tannase in the medium. Above $20 \mathrm{~g} / \mathrm{l}$ of tannic acid both growth and tannase synthesis inhibited but due to availability of substrate (tannic acid) to low concentration of enzyme, the gallic acid formation rate was not drastically altered. In the present study, an initial tannic acid concentration of $15 \mathrm{~g} / \mathrm{l}$ was found to be a better tannase inducer than 10 or $20 \mathrm{~g} / \mathrm{l}$. Earlier most of the reports indicated that a specific tannic acid concentration is suitable for microbial tannase biosynthesis (Hadi et al. 1994; Bradoo et al. 1997). Raghuwanshi et al. (2011) reported maximum tannase production $(11.2 \mathrm{IU} / \mathrm{ml})$ in medium containing $2.0 \%$ tannic acid by Bacillus sphaericus.

The formation of extracellular enzyme is found to be strongly affected by the nature of additional carbon source used. The addition of lactose in tannic acid media enhanced tannase production about 1.7 -fold. The require- ment of additional carbon sources for tannase synthesis by fungal strains in tannic acid media have been reported by many workers (Hadi et al. 1994; Bradoo et al. 1997). Hadi et al. (1994) mentioned that carbohydrates act as a catabolic inducer for tannase biosynthesis in Rhizopus oryzae. Mondal et al. (2000) and Mondal and Pati (2000) observed that the addition of low concentrations of additional carbon sources like glucose, lactose and sucrose (0.1\%) were supportive for enzyme production by $B$. licheniformis KBR6.

The nitrogen source in the culture medium is very essential for microbial growth. Organisms assimilate specific nitrogen source from their surrounding environment and mainly use it as a precursor of amino acid as well as cellular protein synthesis. In this experiment, the bacterium $B$. licheniformis KBR6 synthesized more tannase as well as gallic acids in presence of $\mathrm{NH}_{4} \mathrm{Cl}$. Lekha and Lonsane (1997) have also reported the nutritional requirement of specific nitrogen source in culture media for fungal tannase production. Sabu et al. (2006) reported an increase in the tannase production by Lactobacillus sp. ASR-S1 with $\mathrm{NH}_{4} \mathrm{NO}_{3}$ supplement in the medium containing tamarind seed powder (TSP). Belur et al. (2010a) observed enhanced tannase production by Serratia ficaria in presence of casein hydrolysate and yeast extract with $\mathrm{NH}_{4} \mathrm{NO}_{3}$ in fermentation medium. Raghuwanshi et al. (2011) observed maximum tannase production by Bacillus sphaericus with $0.25 \%$ ammonium chloride. Organic nitrogen sources (beef extract, peptone, etc.) were not used in the medium as these form insoluble complexes with tannic acid. Added advantages of inorganic nitrogen 
sources are that, they are less expensive than organic one and at the same time they avoid the problems of complex formation during enzyme purification.

The inorganic phosphate sources are very much essential for tannase production from B. licheniformis KBR6. Different phosphate compounds in the basal medium for tannase production have been found in earlier reports (Hadi et al. 1994; Bradoo et al. 1997; Lekha and Lonsane 1997). This report is in accordance with the results reported by Das Mohapatra et al. (2009), where enzyme production by $B$. licheniformis KBR6 was optimised using $\mathrm{KH}_{2} \mathrm{PO}_{4}$.

It has been found that $\mathrm{Ca}^{2+}, \mathrm{Mg}^{2+}$ and $\mathrm{Na}^{+}$stimulated the tannase production by $B$. licheniformis KBR6. Micro- and macroelements act as an elementary composition of cell, but a particular ion has stimulatory effect to metabolic synthesis in specific group of microorganisms (Schlegel 1995). Beniwal et al. (2010) showed stimulatory effect of $\mathrm{Ca}^{2+}$ and $\mathrm{Mg}^{2+}$ ions for enzyme production by Enterobacter cloacae MTCC 9125.

Tannase is a most promising and applicable microbial enzyme in bioprocess industry. The enzymatic by product, gallic acid has also many uses in chemical industry. Both tannase and gallic acid can be produced by $B$. licheniformis KBR6 in tannic acid containing culture media. The optimal composition of this medium was tannic acid $(15 \mathrm{~g} / \mathrm{l})$, glucose $(2 \mathrm{~g} / \mathrm{l}), \mathrm{NH}_{4} \mathrm{Cl}(3 \mathrm{~g} / \mathrm{l}), \mathrm{KH}_{2} \mathrm{PO}_{4}(0.5 \mathrm{~g} / \mathrm{l})$ and $\mathrm{MgCl}_{2}$ $(0.5 \mathrm{~g} / \mathrm{l})$. In this minimal medium bacterium can produce tannase in large amounts at short period of cultivation in comparison to other tannase producing fungi.

\section{References}

Aguilar-Zarate P, Cruz MA, Montañez J, Rodriguez-Herrera R, Wong-Paz JE, Belmares RE, Aguilar CN (2015) Gallic acid production under anaerobic submerged fermentation by two bacilli strain. Microb Cell Fact 14:209.

Aissam H, Errachidi F, Penninckx MJ, Merzouki M, Benlemlih M (2005) Production of tannase by Aspergillus niger HA37 growing on tannic acid and olive mill waste waters. World J Microbiol Biotechnol 21:609-614.

Aracri FM, Cavalcanti RMF, Guimaraes LHS (2019) Extracellular tannase from Aspergillus ochraceus: influence of the culture conditions on biofilm formation, enzyme production, and application. J Microbiol Biotechnol 29(11):1749-1759.

Bajpai B, Banerjee T, Patil S (1999) Gallotannin hydrolysis by immobilized fungal mycelia in a packed bed bioreactor. Indian J Exp Biol 37:94-97.

Bajpai B, Patil S (1996) Tannin acyl hydrolase (EC3.1.1.20) activity of Aspergillus, Penicillium, Fusarium and Trichoderma. World J Microbiol Biotechnol 12:217-220.
Bajpai B, Patil S (1997) Induction of tannin acyl hydrolase (EC 3.1.1.20) activity in some members of fungi imperfecti. Enzyme Microb Technol 20:612-614.

Banerjee D, Mondal KC, Pati BR (2001) Production and characterization of extracellular and intracellular tannase from newly isolated Aspergillus aculeatus DBF 9. J Basic Microbiol 41(6):313-318.

Barthomeuf C, Regerat F, Pourrat H (1994) Production, purification and characterization of a tannase from Aspergillus niger LCF 8. J Ferment Bioeng 77(3):320-323.

Belur PD, Mugeraya G, Kuppalu NR (2010a) Temperature and $\mathrm{pH}$ stability of a novel cell- associated tannase of Serratia ficaria DTC. Int J Biotechnol Biochem 6(5):667-674.

Beniwal V, Chhokar V, Singh N, Sharma J (2010) Optimization of process parameters for the production of tannase and gallic acid by Enterobacter cloacae MTCC 9125. J American Sci 6(8):389-397.

Biswas I, Mitra D, Bandyopadhyay AK, Das Mohapatra PK (2020) Contributions of protein microenvironment in tannase industrial applicability: An in-silico comparative study of pathogenic and non-pathogenic bacterial tannase. Heliyon 6:e05359.

Bradoo S, Gupta R, Saxena RK (1997) Parametric optimization and biochemical regulation of extracellular tannase from Aspergillus japonicus. Process Biochem 32(2):135-139.

Cavalcanti RMF, Martinez MLL, Oliveira WP, Guimaraes LHS (2020) Stabilization and application of spray-dried tannase from Aspergillus fumigatus CAS21 in the presence of different carriers. 3 Biotech 10:177.

Coggon P, Sanderson GW (1972) Manufacture of instant tea. Patent Ger. offen 2.304073 (cl. A. 23f.) 16 August 1973.

Das Mohapatra PK, Mondal KC, Pati BR (2005) Effect of inorganic constituents on growth and tannase production by Bacillus licheniformis KBR6. Ind J Biol Sci 70:68-72.

Das Mohapatra PK, Mondal KC, Pati BR (2006). Production of tannase through submerged fermentation of tannincontaining plant extracts by Bacillus licheniformis KBR6. Pol J Microbiol 55(4):297-301.

Das Mohapatra PK, Pati BR, Mondal KC (2009) Effect of amino acids on tannase biosynthesis by Bacillus licheniformis KBR6. J Microbiol Immunol Infect 42(2):172-175.

Deschamps AM, Lebeault JM (1984) Production of gallic acid from tara tannins by bacterial strains. Biotechnol Lett 6(4):237-242.

Deschamps AM, Otuk G, Lebeault JM (1983) Production of tannase and degradation of chestnut tannin by bacteria. J Ferment Technol 61:55-59.

Frost GM, Moss DA (1987) Production of enzymes by fermentation. In Rehm HJ, Reed G, Eds., Biotechnology, Vol. 7a, VCH, Weinheim, 65-102.

Gaathon A, Gross Z, Rozhanski M (1989) Propyl gallate: enzymatic synthesis in a reverse micelle system. Enzyme Microb Technol 11:604-609. 
Hadi TA, Banerjee R, Bhattacharyya BC (1994) Optimization of tannase biosynthesis by a newly isolated Rhizopus oryzae. Bioprocess Eng 11:239-243.

Hagerman AE, Butler LG (1978) Protein precipitation method for the quantitative determination of tannin. J Agric Food Chem 26(4):809-812.

Iibuchi S, Minoda Y, Yamada K (1968) Studies on tannin acyl hydrolase of microorganisms part III. Purification of enzyme and some properties of it. Agr Biol Chem 32(7):803-809.

Jana A, Halder SK, Banerjee A, Paul T, Pati BR, Mondal KC, Das Mohapatra PK (2014) Biosynthesis, structural architecture and biotechnological potential of bacterial tannase: A molecular advancement. Bioresour Technol 157:327-340.

Kim HS, Jeon DY, Javaid HMA, Sahar NE, Lee HN, Hong SJ, Kim YM (2020) Bio-transformation of green tea infusion with tannase and its improvement on adipocyte metabolism. Enzyme Microb Technol 135:109496.

Lekha PK, Lonsane BK (1997) Production and application of tannin acyl hydrolase: State of the art. Adv Appl Microbiol 44:215-260.

Lewis JA, Starkey RL (1969) Decomposition of plant tannins by some soil microorganisms. Soil Sci 107(4):235-241.

Lokeswari N, Sriramireddy D, Sudhakararao P, Varaprasad B (2010) Production of gallic acid using mutant strain of Aspergillus oryzae. J Pharm Res 3(6):1402-1406.

Mondal KC, Banerjee D, Banerjee R, Pati BR (2001a) Production and characterization of tannase from Bacillus cereus KBR9. J Gen Appl Microbiol 47:263-267.

Mondal KC, Banerjee D, Jana M, Pati BR (2001b) Colorimetric assay method for determination of the tannin acyl hydrolase (EC 3.1.1.20) activity. Anal Biochem 295:168-171.

Mondal KC, Banerjee R, Pati BR (2000) Tannase production by Bacillus licheniformis. Biotechnol Lett 22:767-769.

Mondal KC, Pati BR (2000) Studies on the extracellular tannase from newly isolated Bacillus licheniformis KBR6. J Basic Microbiol 40(4):223-232.

Mukherjee G, Banerjee R (2003) Production of gallic acid. Biotechnological routes (Part I). Chimica Oggi 21(1):5962.
Mukherjee G, Banerjee R (2006) Effects of temperature, $\mathrm{pH}$ and additives on the activity of tannase produced by a co-culture of Rhizopus oryzae and Aspergillus foetidus. World J Mirobiol Biotechnol 22:207-212.

Osawa R, Kuroiso K, Goto S, Shimizu A (2000) Isolation of tannin degrading Lactobacilli form humans and fermented foods. Appl Env Microbiol 66(7):3093-3097.

Osawa R, Mitsuoka T (1990) Selective medium for enumeration of tannin-protein complex degrading Streptococcus spp. in faeces of koalas. Appl Env Microbiol 56(11):3609-3611.

Patil DB, Das SK, Das Mohapatra PK, Nag A (2011) Physicochemical studies and optimization of gallic acid production from the seed coat of Terminalia belerica Roxb. Ann Microbiol 61:649-654.

Pourrat H, Regerat F, Morvan P, Pourrat A (1987) Microbiological production of gallic acid from Rhus coriaria. L. Biotechnol Lett 9(10):731-734.

Raghuwanshi S, Dutt K, Gupta P, Misra S, Saxena RK (2011) Bacillus sphaericus: The highest bacterial tannase producer with potential for gallic acid synthesis. J Biosci Bioeng 111(6):635-640.

Rajakumar GS, Nandy SC (1983) Isolation, purification, and some properties of Penicillium chrysogenum tannase. Appl Environ Microbiol 46(2):525-527.

Sabu A, Augur C, Swati C, Pandey A (2006) Tannase production by Lactobacillus sp. ASR-S1 under solid-state fermentation. Proc Biochem 41:575-580.

Scalbert A (1991) Antimicrobial properties of tannins. Phytochem 30(12):3875-3883.

Schlegel HG (1995) Growth of microorganisms. In General Microbiology, Seventh ed., Cambridge University Press, 193-194.

Selwal MK, Yadav A, Selwal KK, Aggarwal NK, Gupta R, Gautam SK (2010) Optimization of cultural conditions for tannase production by Pseudomonas aeruginosa IIIB 8914 under submerged fermentation. World J Microbiol Biotechnol 26:599-605.

Sharma S, Agarwal L, Saxena RK (2007) Statistical optimization for tannase production from Aspergillus niger under submerged fermentation. Indian J Microbiol 47:132-138. 